Bor Pogačnik

Lotrič Meroslovje d. o. o., Slovenija

bor.pogacnik@gmail.com

Aleksander Janeš

Univerza na Primorskem,

Fakulteta za management, Slovenija

aleksander.janes@fm-kp.si

\section{Zadovoljstvo zaposlenih kot ključni dejavnik modela poslovne odličnosti EFQM}

Z uvedbo modela odličnosti Evropske fundacije za management kakovosti (EFQM) organizacije stremijo k doseganju tako kratkoročnih kot tudi dolgoročnih odličnih rezultatov. Organizacije si pri tem pomagajo z napotki v zvezi s temeljnimi načeli odličnosti, ki so s vključena $v$ dejavnike modela EFQM. Implementacija modela $\mathrm{v}$ organizacije prinese različne spremembe, ki lahko različno vplivajo na zaposlene. $\mathrm{Na}$ zadovoljstvo zaposlenih vplivajo različne organizacijske in osebne spremenljivke. Organizacije morajo $\mathrm{v}$ današnjih časih delovati v smeri, da bi ohranile visoko stopnjo zadovoljstva zaposlenih ter tako zadržale zaposlene, ki so ključni prispevek h konkurenčni prednosti. V članku predstavljamo primer podjetja Lotrič Meroslovje, d. o. o., ki je v letu 2019 že drugič prejelo državno nagrado za poslovno odličnost. Slednja je zunanja potrditev odličnosti delovanja podjetja.

Ključne besede: dejavniki, EFQM, poslovna odličnost, spremenljivke zadovoljstva, temeljna načela odličnosti, zadovoljstvo zaposlenih

\section{Employee Satisfaction as a Key Factor in the EFQM Business Excellence Model}

With the implementation of the European Foundation for Quality Management-EFQM business excellence model, organizations strive to achieve both short-term and long-term excellent results. Organizations help themselves to achieve the best results through guidance from the fundamental principles of excellence, which are included in the enablers of the EFQM model. Implementation of the model brings different organizational changes that can affect employees differently. Employee satisfaction is affected by various organizational and personal variables. Organizations today need to work towards maintaining a high level of employee satisfaction and thus retaining employees who are key to contributing to competitive advantage. In this article, we present the case of the company Lotrič Metrology d.o.o., which in 2019 received the national award for business excellence for the second time. This second award is an external confirmation of the excellence of the company's operations.

Keywords: enablers, EFQM, business excellence, satisfaction variables, fundamental principles of excellence, employee satisfaction

(cc)BY-SA https://doi.org/10.26493/1854-4231.16.53-61

\section{Predstavitev podjetja}

Podjetje Lotrič Meroslovje, d.o.o. (v nadaljevanju Lotrič), je poslovno pot začelo v letu 1991, ko je ustanovitelj in generalni direktor $g$. Marko Lotrič pričel z odprtjem obrti za kalibracijo tehtnic, uteži in pipet. V letu 1999 je podjetje pridobilo prvo akreditacijsko listino za kalibracijski laboratorij, leta 2001 akreditacijsko listino za kontrolni organ, 2006 so akreditacijsko listino za kalibracij- ski laboratorij razširili na področje temperature in tlaka, 2014 pa še na področje električnih veličin. Dolžinski laboratorij so odprli v letu 2009. Ustanovili so hčerinska podjetja z vzpostavitvijo akreditiranih laboratorijev v Makedoniji, na Hrvaškem, v Srbiji, Bosni in Hercegovini, kasneje pa tudi v Avstriji in Nemčiji. Z letom 2012 so prevzeli podjetje Lotrič Certificiranje, d. o. o., ki deluje v Železnikih, leta 2018 podjetje PSM merilni 


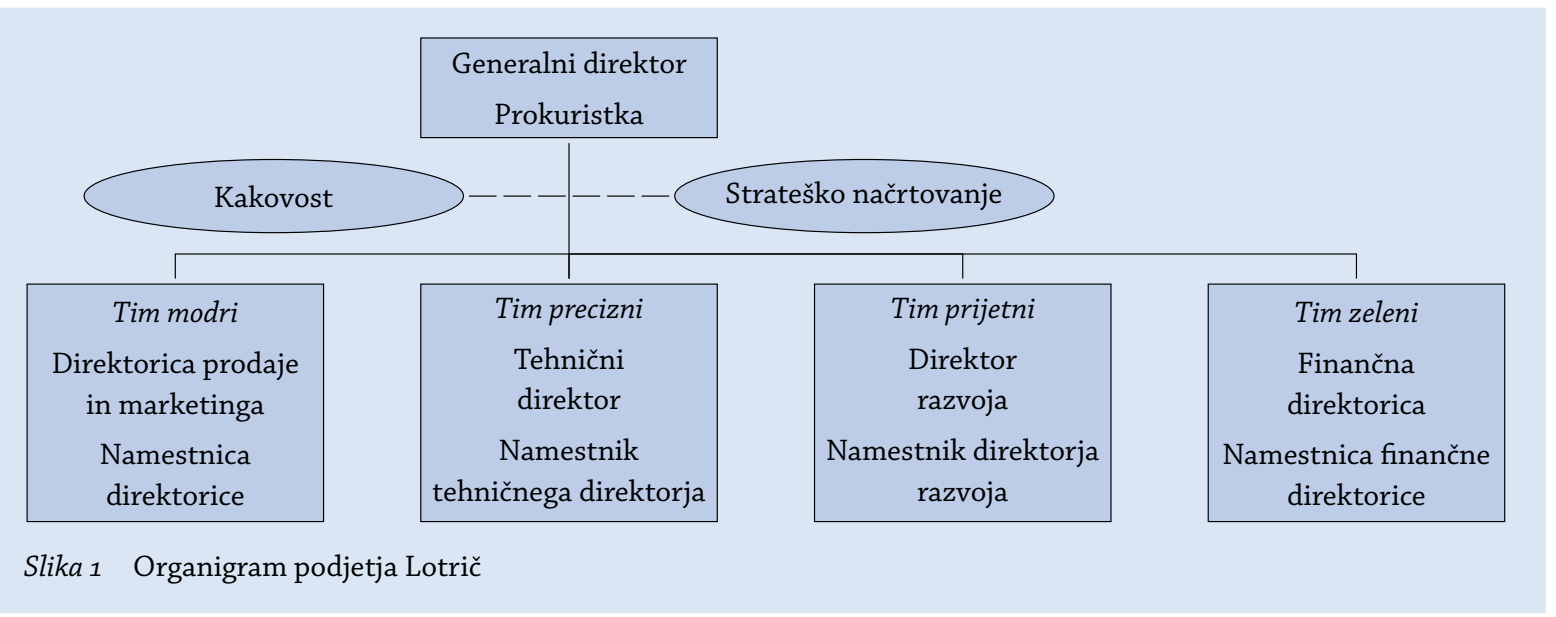

sistemi, d. o. o., ki deluje v Ljubljani, leta 2019 pa podjetje Mikro Medica, d. o. o., ki deluje v Puconcih. V podjetju se osredotočajo tudi na lastne produkte EXACTUM in TRAMES. Svetovno premiero EXACTUM-a na sejmu EXPO beležijo v letu 2015, s produkti TRAMES Unique pa so na tržišče prodrli v letu 2018 (Lotrič Metrology b. 1.).

Podjetje Lotrič je organizirano v štirih timih (slika 1). Tim modri, ki ga vodita direktorica prodaje in marketinga ter njena namestnica, je sestavljen iz oddelkov prodaja, marketing in projekti. Tim precizni, ki ga vodita tehnični direktor in njegov namestnik, je sestavljen iz oddelkov logistika in laboratorij. Laboratorij je razdeljen na oddelke za dolžino, mehaniko, maso, zdravje in mobilnost. Tim prijetni, ki ga vodita direktor razvoja in njegov namestnik, je sestavljen iz oddelkov R\&D, proizvodnja, laboratorij, IKT ter QTree. Laboratorij je razdeljen na oddelka okolje in termo. Tim zeleni, ki ga vodita finančna direktorica in njena namestnica, je sestavljen iz oddelkov računovodstvo, kadrovska služba, nabava, projektna pisarna ter urejanje prostorov in okolice.

V letu 2011 so prejeli priznanje TARAs, leta 2012 pa Priznanje Republike Slovenije za poslovno odličnost. Prejeli so tudi nagrado Bronasta gazela v letu 2012 ter priznanje Zlata nit za najboljšega zaposlovalca med malimi podjetji za leti 2012 in 2016. Podjetje Lotrič je v letu 2019 v kategoriji organizacij z manj kot 250 zaposlenimi iz zasebnega sektorja že drugič prejelo državno nagrado za poslovno odličnost po modelu EFQM 2013 (Urad Republike Slovenije za meroslovje 2013; Lotrič Metrology b. 1.; Spirit: podjetniški portal b. 1.).

\section{Ključni dejavniki EFQM in dodana vrednost za zaposlene}

Model EFQM temelji na evropskih vrednotah iz Evropske konvencije o človekovih pravicah in
Evropske socialne listine. Temeljna načela odličnosti, ki so obravnavana v pričujočem članku, se oblikujejo na podlagi temeljnih človekovih pravic in njihovi splošni veljavi. Model EFQM je praktično, neobvezujoče orodje, ki organizacijam omogoča oceniti, kje na poti k odličnosti so (Urad Republike Slovenije za meroslovje 2013). Zadovoljni zaposleni v vsakem podjetju predstavljajo veliko dodano vrednost, kar pogosto povezujemo $z$ večjo delovno učinkovitostjo ter večjo motiviranostjo zaposlenih. Zaradi hitro spreminjajočih se razmer na trgu in velike konkurence morajo organizacije delati v smeri, da je korist obojestranska, tako za zaposlene kot tudi za organizacijo, in obdržati svoje zaposlene.

Ob pregledu strokovne literature smo ugotovili, da primanjkuje empiričnih raziskav, ki bi se osredotočale na povezavo med zadovoljstvom zaposlenih in modelom EFQM ter z njim povezanimi dejavniki. Prvih pet meril modela predstavlja dejavnike »Voditeljstvo«, »Strategija«, »Zaposleni«, "Partnerstva in viri« ter "Procesi izdelki in storitve«, ki povzemajo delovanje organizacije (Škafar 2018). V podjetju Lotrič smo z rabo dejavnikov modela EFQM 2013 in temeljnih načel odličnosti raziskali, kako so ti povezani z zadovoljstvom zaposlenih.

\section{Metoda raziskave}

Metoda, ki smo jo uporabili, je anketa, merilni inštrument pa anketni vprašalnik (Ivanko 2007). Za izvedbo raziskave smo pridobili dovoljenje vodstva. Anketni vprašalnik smo prilagodili po Prodanovićevi (2012) in ga oblikovali na spletni strani $1 \mathrm{ka}$. Povezavo do anketnega vprašalnika smo po službeni elektronski pošti poslali vsem redno zaposlenim v podjetju (8o). Anketiranje je bilo izvedeno v obdobju od januarja do junija 2021. Anketa je sestavljena iz treh sklopov vprašanj. V prvem 
Vodje se pogovarjajo s podrejenimi o rezultatih dela Vodje vzpodbujajo zaposlene k odgovornemu izvajanju dela Dober delovni rezultat se v našem podjetju hitro opazi in je pohvaljen V našem podjetju med seboj mnogo bolj sodelujemo, kot pa tekmujemo podjetju smo pripravljeni na dodaten napor, kadar se pri delu to zahteva Nadrejeni sprejemajo pripombe na svoje delo

\begin{tabular}{|c|}
\hline \\
4,4 \\
4,5 \\
4,0 \\
4,3 \\
4,1 \\
3,8 \\
\hline
\end{tabular}

Slika 2 Ocena dejavnika »Voditeljstvo«

sklopu smo zastavili demografska vprašanja. V drugem sklopu smo za vsakega od petih dejavnikov modela EFQM zastavili trditve, zaposleni pa so s petstopenjsko Likertovo lestvico ocenjevali, v kolikšni meri se s trditvami strinjajo ( 1 - nikakor se ne strinja, 2 - ne strinja se, 3 - se niti ne strinja niti strinja, 4- strinja se in 5- popolnoma se strinja). Vsakemu dejavniku smo dodali še podvprašanje, ki se navezuje na zadovoljstvo. $V$ tretjem sklopu smo se osredotočili na splošne dejavnike zadovoljstva pri delu, kjer so anketiranci ocenili svoj vpliv na zadovoljstvo. V nadaljevanju nas je zanimalo tudi poznavanje modela EFQM v podjetju ter izboljšave, ki so jih opazili anketiranci, odkar so v podjetju zaposleni. Izpolnjene ankete smo analizirali na spletni strani $1 \mathrm{ka}$ in ugotovitve predstavili opisno ter $\mathrm{v}$ obliki grafov. $\mathrm{V}$ raziskavi je sodelovalo 49 anketirancev. V celoti je bilo izpolnjenih 42 anket, kar predstavlja 52,5-odstotno odzivnost. Pri vsakem vprašanju smo analizirali vse pridobljene odgovore. Zaradi prostorske omejitve so prikazani samo najrelevantnejši rezultati.

\section{Analiza odgovorov anketirancev in razprava Prvi sklop - demografski podatki}

Največji delež anketirancev (43\%) je zaključil srednjo ali poklicno šolo, medtem ko ima zgolj $2 \%$ anketirancev zaključeno osnovno šolo. Univerzitetno izobrazbo ima $24 \%$ anketiranih, $20 \%$ je takih $\mathrm{z}$ višjo ali visokošolsko izobrazbo, $10 \%$ pa jih je zaključilo magisterij ali doktorat.

Največji delež anketirancev ima v podjetju delovno dobo, daljšo od petih let (49\%), nekaj manj (35\%) je takih $\mathrm{z}$ delovno dobo od enega pa do pet let, $16 \%$ pa ima delovno dobo do enega leta.

Največ, kar $35 \%$, anketirancev je predstavljalo zaposlene iz tima precizni. Sledi $29 \%$ anketirancev iz tima modri, nekaj manj ( $27 \%)$ iz tima zeleni in najmanj, $10 \%$, iz tima prijetni.

\section{Drugi sklop - dejavniki modela EFQM podjetja Lotrič}

Voditeljstvo. Zanimalo nas je, ali vodje vzpodbujajo zaposlene k odgovornemu izvajanju dela ter se z njimi pogovarjajo o rezultatih dela, če v podjetju bolj sodelujejo, kot tekmujejo, če so pripravljeni na dodaten napor, kadar se pri delu to zahteva. Spraševali smo tudi, če se delovni rezultat hitro opazi in je pohvaljen ter če nadrejeni sprejemajo pripombe na svoje delo (slika 2).

Anketiranci so s povprečno oceno 4,5 ocenili, $\mathrm{da}$ vodje vzpodbujajo zaposlene $\mathrm{k}$ odgovornemu izvajanju dela. S tem lahko potrdimo enega od napotkov iz načela odličnosti »Vodenje $z$ vizijo, navdihom in integriteto « (Urad Republike Slovenije za meroslovje 2013), ki pravi, da voditelji v podjetju s svojimi dejanji, vedenjem in izkušnjami navdihujejo zaposlene za izboljševanje in odgovornost. Kot sta ugotovila Tari in Molina-Azorín (2010), so vodje primorani razviti kakovostne in trajnostne vrednote, ki jih izkazujejo skozi svoja dejanja.

$S$ povprečno oceno 4,4 anketiranci potrjujejo, da se vodje o rezultatih dela pogovarjajo z zaposlenimi, kar potrjuje enega od napotkov iz temeljnega načela »Trajno doseganje izvrstnih rezultatov«, ki voditelje usmerja v vrednotenje doseženih rezultatov, da bi izboljšali uspešnost delovanja v prihodnosti in zagotovili trajno korist vsem svojim deležnikom (Urad Republike Slovenije za meroslovje 2013). To potrjuje tudi pristop podjetja, ki zagovarja informiranje vseh zaposlenih o uspehih in dosežkih (Lotrič idr. 2019).

Povprečna ocena 4,3 kaže na to, da v podjetju Lotrič delavci med seboj mnogo bolj sodelujejo, kot tekmujejo, kar je eden od pristopov podjetja, ki temelji na timskem delu, kjer zaposleni prevzamejo različne vloge s skupnim končnim ciljem (Lotrič idr. 2019). Kafui Agbozo idr. (2017) so ugotovili, da sodelovanje med zaposlenimi obrodi več sadov kakor samostojno delo, skupek socialnih interakcij pa hkrati pozitivno vpliva na zadovoljstvo zaposlenih.

$\mathrm{V}$ povprečju so anketiranci v podjetju pripravljeni na dodaten napor, kadar delo to zahteva. To dokazuje povprečna ocena 4,1, s katero lahko potrdimo napotek temeljnega načela odličnosti "Agilni management«, da je organizacija fleksibilna in uspešno obvladuje spremembe (Urad Re- 
Pri določanju ciljev poleg direktorjev timov sodelujejo tudi ostali zaposleni

Politika in cilji organizacije so jasni vsem zaposlenim

Cilji, ki jih morajo zaposleni doseči, so realno postavljeni

Slika 3 Ocena dejavnika "Strategija»

publike Slovenije za meroslovje 2013). Anketiranci se s povprečno oceno 4 strinjajo s trditvijo, da se dober delovni rezultat $v$ podjetju hitro opazi in je pohvaljen. To zasledimo $\mathrm{v}$ več napotkih iz temeljnega načela odličnosti »Vodenje $\mathrm{z}$ vizijo, navdihom in integriteto«, ki voditelje spodbujajo $\mathrm{k}$ podpiranju zaposlenih pri doseganju njihovih načrtov, namenov in ciljev ter pravočasno in na ustrezen način priznavajo prizadevanje zaposlenih in njihovih dosežkov (Urad Republike Slovenije za meroslovje 2013; Janežič in Pevec 2021). Stringer (2006) podporo s strani nadrejenih prepoznava kot pomemben vir zadovoljstva zaposlenih.

Kljub temu da napotki iz temeljnega načela odličnosti "Vodenje $z$ vizijo, navdihom in integriteto« voditelje usmerjajo $\mathrm{v}$ pregledovanje in izboljševanje uspešnosti osebnega voditeljskega vedenja (Urad Republike Slovenije za meroslovje 2013; Kafetzopoulos in Gotzamani 2019), se anketiranci s trditvijo, da nadrejeni sprejemajo pripombe na svoje delo, strinjajo $\mathrm{z}$ nekoliko nižjo povprečno oceno 3,8 .

Rezultati anketiranja prikazujejo, da je s sistemom vodenja v podjetju v celoti zadovoljnih $24 \%$ anketirancev, zadovoljnih je $59 \%$, neopredeljenih $13 \%, 2 \%$ anketirancev s sistemom vodenja ni zadovoljnih, prav tako je $2 \%$ takih, ki s sistemom vodenja $\mathrm{v}$ podjetju niso povsem zadovoljni.

Strategija. Glede dejavnika »Strategija« nas je zanimalo, če ima po mnenju zaposlenih podjetje jasno oblikovano poslanstvo, če so politika in cilji organizacije jasni vsem zaposlenim, če pri določanju ciljev poleg direktorjev timov sodelujejo tudi ostali zaposleni in če so cilji, ki jih morajo doseči zaposleni, realno postavljeni (slika 3).

Anketiranci so z najvišjo povprečno oceno, 4,6, ocenili, da ima podjetje jasno oblikovano poslanstvo, kar je po ugotovitvah Srbove in Režňákove (2021) značilno za družinska podjetja, kjer zaposlenim največ pomenijo socialno-emocionalne vrednote, lastniki pa se ne ozirajo na zunanje vlagatelje. To trditev lahko potrdimo $\mathrm{z}$ napotkom načela odličnosti »Trajno doseganje izvrstnih rezultatov«, ki pravi, da podjetje ohranja jasno strategijo za doseganje svojega poslanstva in vizije
(Urad Republike Slovenije za meroslovje 2013; Kafetzopoulos, Gotzamani in Skalkos 2019).

$S$ povprečno oceno 4 anketiranci menijo, da so politika in cilji organizacije jasni vsem zaposlenim. To lahko potrdimo s pristopom podjetja Lotrič, ki temelji na izmenjavi strategij s ključnimi deležniki, kjer se vsem zaposlenim preko delavnic in jasne komunikacije predstavi strategijo (Lotrič idr. 2019; Peace 2010; Škedelj 2016).

Malce nižja, 3,9, je povprečna ocena zaposlenih za trditev, ki pravi, da pri določanju ciljev poleg direktorjev sodelujejo tudi ostali zaposleni. Pri pripravi razvojne strategije je $z$ izvedbo strateških delavnic sodelovalo $40 \%$ zaposlenih (Lotrič idr. 2019).

Eno od temeljnih načel odličnosti je "Razvijanje sposobnosti organizacije«, ki narekuje, da podjetja analizirajo trende uspešnosti svojega delovanja, da bi tako razumela svoje sposobnosti in zmožnosti, kar je ključno za postavljanje ciljev v prihodnosti (Urad Republike Slovenije za meroslovje 2013). Najnižje, s 3,8, so anketiranci v povprečju ocenili trditev, ki pravi, da so cilji, ki jih morajo zaposleni doseči, realno postavljeni.

Odgovori anketirancev prikazujejo, da je s strategijo in $\mathrm{z}$ njeno usmeritvijo $\mathrm{v}$ podjetju v celoti zadovoljnih $22 \%$ anketirancev, zadovoljnih je $64 \%$, neopredeljenih $9 \%, 4 \%$ anketirancev s strategijo ni zadovoljnih, popolnoma nezadovoljnih pa ni.

Zaposleni. Pri tretjem dejavniku, "Zaposleni«, smo poizvedovali, če so zaposleni samostojni pri opravljanju svojega dela, če se v podjetju vodje in sodelavci pogovarjajo sproščeno, prijateljsko in enakopravno, če imajo zaposleni jasno predstavo o tem, kaj se od njih pričakuje pri delu, če se pri usposabljanju upoštevajo tudi njihove želje in če imajo na vseh ravneh realne možnosti za napredovanje. Spraševali smo tudi, če so zaposleni pripravljeni prevzeti tveganje za uveljavitev svojih pobud, če se uspešnost predvidoma vrednoti po dogovorjenih ciljih in standardih ter če imajo $\mathrm{v}$ podjetju sistem napredovanja, ki omogoča, da najboljši zasedejo najboljše položaje (slika 4).

$Z$ najvišjo povprečno oceno, 4,5, so anketiranci ocenili samostojnost zaposlenih pri opravljanju dela. To lahko potrdimo $\mathrm{z}$ napotkom iz 
V našem podjetju se vodje in sodelavci pogovarjamo sproščeno, prijateljsko in enakopravno

Zaposleni smo samostojni pri opravljanju svojega dela
Pri usposabljanju se upoštevajo tudi želje zaposlenih
Zaposleni na vseh nivojih imajo realne možnosti za napredovanje

Zaposleni smo samostojni pri opravljanju svojega dela
Pri usposabljanju se upoštevajo tudi želje zaposlenih
Zaposleni na vseh nivojih imajo realne možnosti za napredovanje

Zaposleni smo samostojni pri opravljanju svojega dela
Pri usposabljanju se upoštevajo tudi želje zaposlenih
Zaposleni na vseh nivojih imajo realne možnosti za napredovanje Imamo sistem napredovanja, ki omogoča, da najboljši zasedejo najboljše položaje Uspešnost se predvidoma vrednoti po dogovorjenih ciljih in standardih Zaposleni smo pripravljeni prevzeti tveganje za uveljavitev svojih pobud Zaposleni imamo jasno predstavo o tem, kaj se od nas pričakuje pri delu

\begin{tabular}{|c|c}
\hline & 4,4 \\
\hline & 4,5 \\
\hline & 4,2 \\
\hline & 3,9 \\
\hline & 3,5 \\
\hline & 3,9 \\
\hline
\end{tabular}

Slika 4 Ocena dejavnika »Zaposleni«

temeljnega načela odličnosti "Doseganje uspehov z nadarjenostjo zaposlenih", ki organizacijam predlaga, da usklajujejo osebne in timske cilje ter pooblaščajo zaposlene za polno izkoriščanje sposobnosti (Urad Republike Slovenije za meroslovje 2013; Akkucuk in Gencer 2017). Občutek samostojnosti in pomembnosti delovne naloge po Sageerju, Rafatovi in Agarwalovi (2012) prispeva k večjemu zadovoljstvu zaposlenih ter slednje spodbuja h kvalitetnemu opravljanju dela.

S povprečno oceno 4,4 so anketiranci potrdili sproščeno, prijateljsko in enakopravno komunikacijo, kar se kaže v razumevanju komunikacijskih potreb zaposlenih za ohranjanje dialoga $\mathrm{v}$ podjetju in je eden od napotkov načela odličnosti "Doseganje uspehov z nadarjenostjo zaposlenih" (Urad Republike Slovenije za meroslovje 2013).

Trditev, da imajo zaposleni jasno predstavo o tem, kaj se od njih pričakuje pri delu, so anketiranci ocenili s povprečno oceno 4,3 . To potrjuje napotek temeljnega načela odličnosti »Razvijanje sposobnosti organizacije«, ki pravi, da odlične organizacije komunicirajo jasno usmeritev in strateški fokus ter da zaposleni razumejo in prikažejo svoj prispevek $\mathrm{k}$ stalnemu uspehu organizacije (Urad Republike Slovenije za meroslovje 2013).

4,2 je bila povprečna ocena strinjanja anketirancev s trditvijo, da se pri usposabljanju upoštevajo tudi želje zaposlenih. Pristop podjetja Lotrič (Lotrič idr. 2019) namreč temelji na upoštevanju želja zaposlenih, skladno $\mathrm{z}$ razvojem procesa delovnih mest in zahtevanih kompetenc. Odlične organizacije zaposlenim za njihov največji prispevek zagotavljajo potrebna sredstva in usposabljanja (Manders, de Vries in Blind 2016; Kafetzopoulos in Gotzamani 2019).

Anketirani zaposleni se s trditvijo, da imajo na vseh svojih ravneh realne možnosti za napredovanje, strinjajo s povprečno oceno 3,9. Eden od napotkov temeljnih načel odličnosti, povezan z dejavnikom "Zaposleni« (Urad Republike Slovenije za meroslovje 2013), organizacije usmerja v usklajevanje plač, nagrad in drugih pogojev zaposlova- nja s transparentnimi strategijami in politikami.

S povprečno oceno 3,9 so anketiranci ocenili tudi pripravljenost prevzema tveganja za uveljavitev pobud s strani zaposlenih. Uveljavitev pobud zaposlenih povezujemo tudi $z$ inovativnostjo in ustvarjalnostjo, kar odlične organizacije podpirajo z dopuščanjem odprtega razmišljanja zaposlenih. To organizacijam narekuje napotek temeljnega načela odličnosti "Spodbujanje ustvarjalnosti in inovativnosti« (Urad Republike Slovenije za meroslovje 2013; Hojč 2019).

Uspešnost se predvidoma vrednoti po dogovorjenih ciljih in standardnih, kar je še ena od zastavljenih trditev, ki so jo anketiranci ocenili z za odtenek slabšo povprečno oceno $(3,8)$. Eden od napotkov iz načela odličnosti »Doseganje uspehov z nadarjenostjo zaposlenih" narekuje, da v odličnih organizacijah v naprej določijo znanja in veščine kot tudi kompetence in ravni delovne uspešnosti zaposlenih, ki so potrebne za doseganje ciljev (Urad Republike Slovenije za meroslovje 2013).

$Z$ najnižjo povprečno oceno, ki znaša 3,5 , so anketiranci ocenili trditev, da v podjetju obstaja sistem napredovanja, ki najboljšim omogoča zasedanje najboljših položajev. V podjetju Lotrič zagovarjajo razpršenost odgovornosti (Lotrič idr. 2019), ki mora biti pravilno usmerjena.

$\mathrm{Z}$ odnosom do zaposlenih je v celoti zadovoljnih $34 \%$ anketirancev, zadovoljnih je $48 \%$, neopredeljenih pa $16 \%$. Le $2 \%$ anketirancev je mnenja, da jim odnos podjetja do zaposlenih povsem ne ustreza.

Partnerstva in viri. Pri dejavniku "Partnerstva in viri« smo od zaposlenih želeli izvedeti, ali v podjetju razvijajo, izboljšujejo in uvajajo nove tehnologije, ali s partnerji ter dobavitelji gradijo dolgotrajne odnose in prepoznavajo priložnosti za ključna partnerstva. Zanimalo nas je tudi, če v podjetju sredstva izrabljajo na okolju prijazen način in dobro izkoriščajo finančne ter materialne vire (slika 5). 
V podjetju prepoznavamo priložnosti za ključna partnerstva $\quad$ 4,2

S partnerji ter dobavitelji gradimo dolgotrajne odnose $\quad 4,4$

$\begin{array}{ll}\text { V podjetju razvijamo, izboljšujemo in uvajamo nove tehnologije } & 4,5\end{array}$

Sredstva izrabljamo na okolju prijazen način $\quad 4,1$

V podjetju dobro izkoriščamo finančne in materialne vire $\quad 4,0$

Slika 5 Ocena dejavnika »Partnerstva in viri«

Procesi dela se v podjetju stalno nadgrajujejo $\quad$ 4,2

Ob uveljav. novih procesov se upošteva tudi mnenje zap. oziroma ljudi, udelež. v procesu $\quad$ 4,2

Naše izdelke in storitve stalno izboljšujemo in posodabljamo $\quad 4,5$

Vzdržujemo ter krepimo odnose z odjemalci $\quad 4,4$

Slika 6 Ocena dejavnika »Procesi, izdelki in storitve»

Z najvišjo povprečno oceno $(4,5)$ so anketiranci ocenili razvijanje, izboljševanje in uvajanje novih tehnologij v podjetju, kar dokazujeta razvoj in implementacija lastnega informacijskega sistema QTree, ki ga uporabljajo vsi zaposleni (Lotrič idr. 2019). To lahko povežemo tudi $z$ napotkom temeljnega načela odličnosti "Agilni management « (Urad Republike Slovenije za meroslovje 2013), ki pravi, da odlične organizacije vrednotijo in razvijajo tehnološki portfelj za hitro ter učinkovito prilagajanje procesov (Uygur in Sümerli 2013).

S povprečno oceno 4,4 so anketiranci ocenili oblikovanje dolgotrajnih odnosov s partnerji in $\mathrm{z}$ dobavitelji, kar potrjuje še eden od napotkov načela odličnosti »Razvijanje sposobnosti organizacije«, ki organizacijam predlaga grajenje trajnih odnosov s partnerji ter dobavitelji, ki temeljijo na spoštovanju, zaupanju in odprtosti (Urad Republike Slovenije za meroslovje 2013).

Prepoznavanje ključnih partnerstev so anketiranci v povprečju ocenili z oceno 4,2. Načelo odličnosti "Razvijanje sposobnosti organizacije» (Urad Republike Slovenije za meroslovje 2013) ima prepoznavanje ključnih partnerjev za enega pomembnejših elementov pri povečanju lastnih sposobnosti (Calvo-Mora idr. 2020).

$S$ povprečno oceno 4,1 so anketiranci ocenili izkoriščanje sredstev na okolju prijazen način, kar potrjuje tudi eden od pristopov podjetja, $s$ katerim se zavzemajo za varno ter zdravo delovno okolje in si stalno prizadevajo za zmanjšanje vpliva na okolje (Lotrič idr. 2019). Lazič (2019) navaja, da je skrb za naravno okolje eden od pomembnejših pristopov za ustvarjanje trajnostne prihodnosti.

Anketiranci so s povprečno oceno (4) ocenili dobro izkoriščanje finančnih in materialnih virov $\mathrm{v}$ podjetju. Ker je ocena 4 relativno visoka, lahko to potrdimo z napotkom iz načela »Ustvarjanje trajnostne prihodnosti«, ki organizacije spodbuja, da namenjajo sredstva za zadovoljevanje dolgoročnih potreb in ne zgolj za kratkoročni dobiček (Urad Republike Slovenije za meroslovje 2013).

S trditvijo, da so zaposleni zadovoljni s tem, kako podjetje upravlja s partnerji, $\mathrm{z}$ dobavitelji ter viri, se popolnoma strinja $37 \%$ anketirancev, strinja se $49 \%, 16 \%$ pa je neopredeljenih. Pri tem le $2 \%$ anketirancev s tem ni zadovoljno, prav tako pa je $2 \%$ takšnih, ki so s tem v celoti nezadovoljni.

Procesi, izdelki in storitve. Glede petega dejavnika smo poizvedovali, če v podjetju storitve in izdelke stalno izboljšujejo in posodabljajo, vzdržujejo in krepijo odnose z odjemalci, če se ob uveljavljanju novih procesov upošteva tudi mnenje zaposlenih oziroma ljudi, udeleženih v procesu, in če se procesi dela v podjetju stalno nadgrajujejo (slika 6).

Najvišje, s povprečno oceno 4,5 , so anketiranci ocenili stalno izboljševanje in posodabljanje izdelkov ter storitev, kar potrjuje napotek temeljnega načela odličnosti »Dodajanje vrednosti za odjemalce«, ki pravi, da si odlične organizacije prizadevajo za inoviranje in ustvarjanje vrednosti za svoje odjemalce (Tari in Molina-Azorín 2010; Urad Republike Slovenije za meroslovje 2013). To potrjujejo $\mathrm{z}$ razvojem ter izdelavo lastnih unikatnih merilnih in nadzornih sistemov.

$S$ povprečno oceno 4,4 so anketiranci ocenili vzdrževanje in krepitev odnosov z odjemalci, ki je eden od ključnih elementov (Urad Republike Slovenije za meroslovje 2013) in podjetju pomaga pri povečanju vrednosti za odjemalce ter ostale deležnike. Peterc Zidarjeva in Skrinar (2021) navajata, da morajo organizacije poznati potrebe svojih odjemalcev in z njim graditi dolgoročne odnose preko transparentne izmenjave informacij. 
Upoštevanje mnenj zaposlenih ob uveljavljanju novih procesov so anketiranci v povprečju ocenili z oceno 4,2. V podjetju Lotrič so $\mathrm{z}$ uvedbo modela EFQM preoblikovali procese dela, pri čemer je sodelovala tretjina zaposlenih (Lotrič idr. 2019).

Enako $(4,2)$ so anketiranci v povprečju ocenili tudi stalno nadgrajevanje procesov dela $\mathrm{v}$ podjetju. Glede na področje dela so določili skrbništva procesov in s tem dodelili odgovornost pri razvijanju, vzdrževanju in izboljševanju procesov, ki podjetju omogoča stalni nadzor in merljivost ter je ključno za izboljšave ali nadgradnjo procesov (Urad Republike Slovenije za meroslovje 2013; Lotrič idr. 2019).

Glede dejavnika »Procesi, izdelki in storitve« je $33 \%$ anketirancev $v$ celoti zadovoljnih $z$ razvijanjem, obvladovanjem in izboljševanjem procesov, izdelkov ter storitev, kar $60 \%$ pa je s tem zadovoljnih. Sledi, da je bilo $5 \%$ anketirancev neopredeljenih, le $2 \%$ pa je takšnih, ki s tem niso zadovoljni.

\section{Tretji sklop - splošni dejavniki, ki vplivajo na zadovoljstvo zaposlenih in EFQM}

Kar $79 \%$ anketirancem dobri odnosi med zaposlenimi predstavljajo največji vpliv na njihovo zadovoljstvo, kar je pomembno zlasti v manjših in srednje velikih podjetjih, kjer zaposleni med seboj običajno bolj sodelujejo in komunicirajo. V podjetju Lotrič so naklonjeni predstavitvi in spoznavanju vseh novozaposlenih in povezovanju zaposlenih na delovnem mestu (Lotrič idr. 2019). Dobre odnose med zaposlenimi tako lahko vključimo $\mathrm{v}$ eno izmed organizacijskih spremenljivk zadovoljstva "Delovna skupina" in jih povezujemo z enim od napotkov načela »Doseganje uspehov z nadarjenostjo zaposlenih « iz dejavnika »Zaposleni«, ki organizacije spodbuja k podpiranju kulture medsebojne pomoči, priznavanja in skrbi med posamezniki in timi (Sageer, Rafat in Agarwal 2012; Urad Republike Slovenije za meroslovje 2013). Podobno so anketiranci ocenili tudi dejavnike »Ustrezni delovni pogoji«, »Dobri odnosi z nadrejenimi« ter "Občutek dobro opravljenega dela«, ki so jih v $71 \%$ označili za dejavnike, ki v celoti vplivajo na zadovoljstvo pri delu. Tudi te tri splošne dejavnike lahko povežemo $\mathrm{z}$ dejavniki iz meril modela EFQM (Locke 1976; Urad Republike Slovenije za meroslovje 2013). Ustrezne delovne pogoje, kar uvrščamo med organizacijska spremenljivke (Sageer, Rafat in Agarwal 2012), opisuje napotek iz dejavnika "Partnerstva in viri«, ki organizacijam narekuje, da kar najbolje uporabljajo in uspešno obvladujejo svoje zgradbe, opremo in

\begin{tabular}{|c|c|c|c|c|c|}
\hline $\begin{array}{ll}\text { Preglednica } 1 \text { Vpliv splošnih dejav } \\
\text { pri delu }\end{array}$ & ikov & & adov & & \\
\hline Postavka & (1) & (2) & (3) & (4) & (5) \\
\hline Stalnost zaposlitve & 0 & 2 & 10 & 48 & 40 \\
\hline Zanimivost dela & o & o & 2 & 36 & 62 \\
\hline Redna plača in druge ugodnosti & o & o & o & 38 & 62 \\
\hline Ustrezni delovni pogoji & o & o & o & 29 & 71 \\
\hline Delovni čas & o & o & 7 & 33 & 60 \\
\hline Možnosti napredovanja & o & 5 & 12 & 52 & 31 \\
\hline Dobri odnosi med zaposlenimi & o & o & 2 & 19 & 79 \\
\hline Dobri odnosi z nadrejenimi & o & o & 2 & 26 & 71 \\
\hline Samostojnost in ustvarj. pri delu & o & o & 5 & 38 & 57 \\
\hline Občutek dobro opravljenega dela & o & o & o & 29 & 71 \\
\hline Pohvala nadrejenega & 2 & o & 5 & 31 & 62 \\
\hline Prevzemanje odgovornosti & 2 & 2 & 5 & 48 & 43 \\
\hline Zadovoljstvo odjemalcev & 2 & o & 5 & 36 & 57 \\
\hline Občutek pripadnosti podjetju & 2 & o & 2 & 31 & 64 \\
\hline Drugo & o & o & o & 67 & 33 \\
\hline
\end{tabular}

materiale. Dobre odnose $\mathrm{z}$ nadrejenimi, eno od organizacijskih spremenljivk zadovoljstva, opisuje napotek iz dejavnika »Voditeljstvo«, ki spodbuja, da se po celotni verigi vrednosti vzpostavlja etičnost ter kulturo zaupanja in odprtosti. Občutek dobro opravljenega dela lahko povezujemo s spremenljivko "Zadovoljstvo z delom« (Sageer, Rafat in Agarwal 2012), kar spodbuja tudi napotek iz dejavnika »Zaposleni«, ki pravi, da odlične organizacije sporočajo jasno usmeritev in strateški fokus ter tako zagotovijo, da zaposleni razumejo in prikažejo svoj prispevek $\mathrm{k}$ stalnemu uspehu organizacije (Kawiana idr. 2018). Najmanjši vpliv na zadovoljstvo anketirancem predstavlja dejavnik »Možnosti napredovanja« (zelo vpliva - 31 \%; vpliva - $52 \%$ ), pri čemer je $12 \%$ anketirancev neopredeljenih, pri $5 \%$ anketirancev pa ta dejavnik ne vpliva na zadovoljstvo (preglednica 1).

Pri zadnjem vprašanju nas je najprej zanimalo poznavanje modela EFQM. Analiza rezultatov je pokazala, da je $14 \%$ anketirancev mnenja, da sta jim model kot tudi njegova uporaba v podjetju popolnoma znana, $33 \%$ anketirancem pa sta znana. Kar $43 \%$ je glede trditve o poznavanju modela ter njegovi uporabi neopredeljenih. Sledi, da $7 \%$ anketirancev modela ne pozna, $2 \%$ anketirancev pa modela v celoti ne pozna (preglednica 2).

Zanimalo nas je tudi, na katerih področjih an- 
Preglednica 2 Poznavanje modela EFQM in njegove rabe

\begin{tabular}{lrrrrr}
\hline Postavka & (1) & (2) & (3) & (4) & (5) \\
\hline Model poslovne odličnosti EFQM & 2 & 7 & 43 & 33 & 14 \\
poznam in razumem, kako ga upo- & & & & & \\
rabljamo v našem podjetju & & & & & \\
\hline
\end{tabular}

Opombe V odstotkih. Naslovi stolpcev: (1) sploh se ne strinjam, (2) se ne strinjam, (3) niti se strinjam, niti se ne strinjam, (4) se strinjam, (5) popolnoma se strinjam.

ketiranci, odkar so v podjetju zaposleni, opazijo izboljšave. Anketiranci so posamezne odgovore ocenjevali $z$ ocenami od 1 do 5 .

Z najvišjo povprečno oceno $(4,4)$ so ocenili materialne delovne pogoje. Odgovoru sta sledila še prepoznavnost v Sloveniji s povprečno oceno 4,3 in družbena odgovornost podjetja $z$ oceno 4,2. Tudi Gómez-Lópezova, Serrano-Bedia in LópezFernándezova (2019) so ugotovile, da organizacije ob korektni implementaciji modela EFQM izboljšajo svojo zunanjo podobo. Po vrsti so si sledile še izboljšave glede zadovoljstva odjemalcev $(4,1)$, ekonomske uspešnosti podjetja (4,1), možnosti za izobraževanje $(4,1)$, samostojnosti in ustvarjalnosti pri delu (4) ter prepoznavnosti v mednarodnem okolju (4). Nekoliko manjše izboljšave so anketiranci v povprečju opazili pri izvajanju procesov v podjetju $(3,9)$, odnosih med zaposlenimi $(3,9)$, obveščenosti znotraj podjetja $(3,9)$, možnosti napredovanja $(3,8)$ in ravni motiviranosti zaposlenih $(3,8)$. Najmanjše izboljšave so zaznali pri ravni pripadnosti zaposlenih podjetju, kar so $\mathrm{v}$ povprečju ocenili z oceno 3,5 .

\section{Sklep in priporočila}

Ugotovili smo, da so zaposleni v podjetju Lotrič najzadovoljnejši z dejavnikom »Procesi, izdelki in storitve«, na njihovo zadovoljstvo pa imajo največji vpliv organizacijske spremenljivke, ki jih povezujemo z dejavniki "Zaposleni«, "Voditeljstvo« ter "Partnerstva in viri«. Med ugotovitvami lahko izpostavimo dve najnižji povprečni oceni med vsemi trditvami ankete. Prva je glede dejavnika »Zaposleni«, da je v podjetju takšen sistem napredovanja, ki najboljšim omogoča zasedanje najboljših položajev, in v povprečju znaša 3,5. Druga najnižja ocena pa je na področju izboljšav, kjer so anketiranci najmanjše izboljšave zaznali pri ravni pripadnosti zaposlenih podjetju, kar so v povprečju ocenili z oceno 3,5. Obe najnižji oceni oziroma vse ostale višje lahko vidimo v luči odličnosti, ki jo podjetje izkazuje pri preučevanih dejavnikih modela EFQM. Slednji so obenem vzroki za re- zultate, ki jih podjetje izkazuje na vseh trgih delovanja.

Kljub očitno nadpovprečnim pozitivnim ocenam anketirancev glede povezave med zadovoljstvom zaposlenih in dejavniki modela EFQM smo oblikovali nekaj priporočil. Glede na dobljene rezultate pri dejavniku »Voditeljstvo« managerjem podjetja Lotrič priporočamo, da v največji možni meri sprejemajo komentarje in predloge ter s tem še dodatno izboljšujejo uspešnost osebnega voditeljskega vedenja. Glede na dobljene rezultate dejavnika "Strategija« priporočamo, da natančno analizirajo trende uspešnosti delovanja in tako glede na predvideno zmožnost zaposlenim postavijo realno dosegljive cilje. Na osnovi analize dejavnika "Zaposleni« priporočamo rabo jasnega sistema razporejanja odgovornosti, ki najbolj usposobljenim omogoča zasedanje vodilnih in vodstvenih položajev. Ker je več kot polovica anketirancev ocenilo, da model EFQM in njegovo rabo $\mathrm{v}$ podjetju slabše pozna, priporočamo izvedbo rednih usposabljanj zaposlenih in njihovo vključevanje v praktično uporabo managerskih orodij.

\section{Literatura}

Akkucuk, U., in Y. G. Gencer. 2017. »EFQM Model and Sustainability of Organizations." Prispevek predstavljen na 2nd International Conference on Advances in Management Engineering and Information Technology, Šanghaj, Kitajska, 23.-24. april.

Calvo-Mora, A., A. Blanco-Oliver, J. L. Roldán in R. Periáñez-Cristóbal. 2020. "TQM Factors and Organisational Results in the EFQM Excellence Model Framework. Industrial Management \& Data Systems 120 (12): 2297-2317.

Gómez-López, R., A. M. Serrano-Bedia in M. C. LópezFernández. 2019. "An Exploratory Study of the Results of the Implementation of EFQM in Private Spanish Firms."International Journal of Quality \& Reliability Management 36 (3): 331-346.

Hojč, D. 2019. »Model vpliva dodane vrednosti za odjemalce ter inovativnost. "Revija za univerzalno odličnost 8 (2): 169-178.

Ivanko, Š. 2007. Raziskovanje in pisanje del: metodologija in tehnologija raziskovanja ter pisanja strokovnih in znanstvenih del. Kamnik: Cubus image.

Janežič, D., in N. Pevec. 2021. "Vodenje z vizijo, navdihom in integriteto. "Revija za univerzalno odličnost $10(1): 41-56$.

Kafetzopoulos, D., in K. Gotzamani. 2019. »Investigating the Role of EFQM Enablers in Innovation Performance. "The TQM Journal 31 (2): 239-256.

Kafetzopoulos, D., K. Gotzamani in D. Skalkos. 2019. "The Relationship between EFQM Enablers and Business Performance: The Mediating Role of Innovation. « Journal of Manufacturing Technology Management 30 (4): 684-706. 
Kafui Agbozo, G., I. S. Owusu, M. A. Hoedoafia in Y. B. Atakorah. 2017. "The Effect of Work Environment on Job Satisfaction: Evidence from the Banking Sector in Ghana." Journal of Human Resource Management 5 (1) 12-18.

Kawiana, I. G. P., L. K. C. Dewi, L. K. B. Martini in I. B. R. Suardana. 2018. "The Influence of Organizational Culture, Employee Satisfaction, Personality, and Organizational Commitment Towards Employee Performance. « International Research Journal of Management, IT and Social Sciences 5 (3): 35-45.

Lazič, A. 2019. »Ustvarjanje trajnostne prihodnosti organizacij.« Revija za univerzalno odličnost 8 (1): 99109.

Locke, E. A. 1976. »The Nature and Causes of Job Satisfaction."V Handbook of Industrial and Organizational Psychology, ur. Marvin D. Dunnette, 1297-1349. Chicago, IL: Rand McNally.

Lotrič Metrology. B.1. "O nas.» https://www.lotric.si /si/podjetje/o-nas.

Lotrič, M., T. Berce, A. Bešter, T. Bevk, J. Bobar, K. Čufar, Š. Demšar, T. Ferenčak, U. Habjan, P. Hafner, T. Jelenc, K. Lotrič Kejžar, M. Lotrič, M. Lotrič, T. Šinkovec Fejfar, J. Thaler in A. Tolar. "Vloga za priznanje Republike Slovenije za poslovno odličnost za leto 2019.« Interno gradivo, Lotrič Meroslovje.

Manders, B., H. J. de Vries in K. Blind. 2016. »ISO 9001 and Product Innovation: A Literature Review and Research Framework." Technovation 48 (1): 41-55.

Peace, W. H. 2010. »Hard Work of Being a Soft Manager."V Leadership Insight: 15 Unique Perspectives on Effective Leadership, 103-108. Boston, MA: Harvard Business School.

Peterc Zidar, M. P., in U. Skrinar. 2021. »Dodajanje vrednosti za odjemalce.« Revija za univerzalno odličnost 10 (1): 1-13.
Prodanović, S. 2012. „Vpeljava sistema odličnosti po modelu EFQM kot sredstvo motivacije zaposlenih.« Magistrsko delo, Fakulteta za državne in evropske študije.

Sageer, A., S. Rafat in P. Agarwal. 2012. "Identification of Variables Affecting Employee Satisfaction and Their Impact on the Organization. " Journal of Business and Management 5 (1): 32-39.

Spirit: podjetniški portal. B.1. »Dobitniki priznanj RS za poslovno odličnost.« https://www.podjetniski -portal.si/poslovna-odlicnost/dobitniki-priznanj -rs-za-poslovno-odlicnost.

Srbová, P., in M. Režňáková. 2021. „The Family Influence on Business: Czech Family Companies. "SHS Web of Conferences 92 (2): 05025. https://www.doi .org/10.1051/shsconf/20219205025.

Stringer, L. 2006. "The Link between the Quality of the Supervisor-Employee Relationship and the Level of the Employee's Job Satisfaction." Public Organization Review 6 (2): 125-142.

Škafar, B. 2018. Sistemi vodenja kakovosti in modeli odličnosti: ključni dejavniki (ne) uspešnega delovanja. Novo mesto: Fakulteta za organizacijske študije.

Škedelj, J. 2016. "Vodenje proizvodnje z uporabo modela odličnosti EFQM.«Revija za univerzalno odličnost 5 (3): 251-26o.

Tari, J. J., in J. F. Molina-Azorín. 2010. "Integration of Quality Management and Environmental Management Systems." The TQM Journal 22 (6): 687-701.

Urad Republike Slovenije za meroslovje. 2013. Model odličnosti EFQM. Celje: Ministrstvo za gospodarski razvoj in tehnologijo.

Uygur, A., in S. Sümerli. 2013. "EFQM Excellence Model."International Review of Management and Business Research 2 (4): 980-993. 